\title{
Screening of chickpea (Cicer arietinum L.) germpalsm against ascochyta blight [Ascochyta rabiei (Pass.) Lab.] correlation and combining ability analysis for various quantitative traits
}

\author{
Qurban Ali ${ }^{1 *}$, Muhammad Iqbal ${ }^{2}$, Arbab Ahmad ${ }^{2}$, Muhammad Hammad Nadeem Tahir ${ }^{1}$, \\ Muhammad Ahsan ${ }^{1}$, Nazir Javed ${ }^{2}$ and Jehanzeb Farooq ${ }^{1}$ \\ ${ }^{1}$ Department of Plant Breeding and Genetics, University of Agriculture Faisalabad, Pakistan. \\ ${ }^{2}$ Department of Plant Pathology, University of Agriculture Faisalabad, Pakistan.
}

Accepted 15 May, 2013

\begin{abstract}
The present study was conducted to estimate correlation and combining ability analysis among quantitative traits in chickpea (Cicer arietinum L.) during 2008 to 2010. Ten chickpea varieties/lines (08AG-004, CH-70/02, CH-76/02,. Nine lines viz. AUG-27, M-98, 114, 115, 117, 781, 1049, 4025, and 5006 exhibited moderately NOOR-91, K-70005, K-70008, K-70022, CM-2008, YN-08004 and K-70009) were evaluated for the source of resistance against Ascochyta rabiei but none was found highly resistant. However, four lines (08-AG-004, $\mathrm{CH}-70 / 02, \mathrm{CH}-76 / 02$ and NOOR-91) were moderately resistant and five lines (K-70005, K-70008, K-70022, CM-2008 and YN-08004) exhibited moderately susceptible reaction. Among twenty varieties/lines were evaluated for the source of resistance but none was found highly resistant and two lines 101 and 620 were resistant. However, four lines viz. Paidar-91, Pb-2000, 818 and 870 were found to be moderately resistantsusceptible reaction and three lines 205, 1205, and 1288 exhibited susceptible reaction. The genotypes Paidar-91, 620, PB-2000, 101 and 870 were crossed in $5 \times$ 5 diallel fashion. The general combining ability (GCA) and specific combining ability (SCA) effects for various quantitative traits like days taken to flowering, days taken to maturity, plant height, primary branches per plant, secondary branches per plant, number of pods per plant, seeds per pod, plant biomass, 100 -seed weight, number of grains per plant and seed yield per plant were ascertained.
\end{abstract}

Key words: Ascochyta rabiei, Cicer arietinum, blight, chickpea, germplasm, diallel.

\section{INTRODUCTION}

Among the pulses, chickpea (Cicer arietinum L.) is the third leading grain legume in the world and first in the South Asia. $92 \%$ of the area and $75.4 \%$ of the production of grain are concentrated in semi-arid tropical countries (Anonymous, 2006-2007). Its range of cultivation extends from the Mediterranean basin to the Indian sub-continent and south ward of Ethiopia and the East African highlands. Two types of chickpea, one namely Kabuli is grown in temperate regions while the desi type chickpea is grown in the semi-arid tropics (Muehlbauer and Singh, 1987). Chickpea is the rabi pulse crop and important source of calories in Pakistan which is predominantly grown in the vast rainfed areas of the country. Pakistan ranks second to India in terms of acreage under chickpea 
which is 1050 thousand hectares with an annual production of 571 thousand tones (Anonymous, 20092010). It is rich and readily available source of protein both for human and animals. The average yield of chickpea is low as compared to other chickpea growing countries. In Punjab about $90 \%$ chickpea is cultivated in rainfed areas; the major chickpea production belt is Thal including the districts of Bhakkhar, Mianwali, Layyah, Khushab and parts of Jhang. Chickpea is the cheapest and readily available source of protein (19.5\%), fats (1.4\%), carbohydrates (57 to 60$)$, ash (4.8\%) and (4.9 to $15.59 \%$ ) moisture (Huisman and Van der Poel, 1994). It makes up the deficiency of cereal diets. It also helps in replenishment of soil fertility by fixing of atmospheric nitrogen through symbiosis coupled with deep root system.

Chickpea blight (Ascochyta rabiei Pass. Lab.) is the most serious disease of chickpea, which causes considerable degradation in quality and yield of the crop stand. Ascochyta blight disease occurs in epidemic form during the year receiving more than $350 \mathrm{~mm}$ rain fall (Nene and Reddy, 1987; Jimenez-Diaz et al., 1993; Acikgoz et al., 1994; Mucella et al., 2004). It has been reported to cause 50 to $70 \%$ crop losses (Malik and Bashir, 1984) under favourable atmospheric condition for the disease development. Sometimes it may cause failure of the whole chickpea crop. Disease epidemics in Pakistan as well as in different parts of the world have been reported (Nene, 1982; Aslam, 1984; Kaiser, 1992). The disease can effectively be managed by the foliar application and seed dressing fungicides (Reddy and Singh, 1984; Rauf et al., 1996), use of disease free seed, destruction of plant disease debris (Chaube and Pandey, 1986) and host plant resistance (Iqbal et al., 2002; Ahmad et al., 2006). However, due to lack of durable resistance in commercial chickpea cultivars (Iqbal et al., 1989) because the virulences of the pathogen are constantly changing in nature, previously released resistant cultivars have become susceptible due to appearance of new virulent strains/races (Jamil et al., 1995; Armstrang et al., 2001). Thus there is a need to continuously explore and identify the sources of resistance in chickpea germplasm and its incorporation into high yielding quality commercial chickpea varieties (Bashir et al., 1997). The main objectives of study were the identification and development of blight resistant chickpea genotypes.

\section{MATERIALS AND METHODS}

\section{Screening of chickpea germplasm for the source of resistance} against $A$. rabiei

Twenty lines/entries of chickpea germplasm were obtained from Department of Plant Breeding and Genetics, University of Agriculture, Faisalabad (PBG-UAF) and ten lines/entries were collected from Pulses Research Institute (PRI), Ayub Agricultural Research Institute (AARI), Faisalabad and Nuclear Institute for
Agriculture and Biology (NIAB), Faisalabad. Lines/entries obtained from PBG-UAF consisted of 698, 820, 205, 1205, 1288, AUG-27, M-98, 114, 115, 117, 781, 1049, 4025, 5006, Paidar-91, Pb-2000, $818,870,101,620$ whereas lines/entries collected from PRI, Faisalabad were K-70009, K-70005, K-70008, K-70022, CM-2008, YN-08004, 08-AG-004, NOOR-91 and CH-70/02, CH-76/02 from NIAB, Faisalabad.

The test entries were sown in a single row sub-plot of $4 \mathrm{~m}$ length and $30 \mathrm{~cm}$ row spacing in a Randomized Complete Block Design (RCBD) with three replications during 2007-2008. The highly susceptible variety Punjab-1, as a check was planted as a single row after every two test lines of the germplasm for disease spread in the field and its distribution to test line on each side. Diseased pods of chickpea showing characteristics symptoms of blight disease were obtained from PRI and were kept at 5 to $8^{\circ} \mathrm{C}$ until used for the isolation of $A$. rabiei. The isolation was carried out by the procedure followed by the llyas and lqbal (1986). Infected pods, by holding them in a forceps were surface flamed in such a way that only charring of outer pod layer could occur but the inner pod layer remained intact. The pods were then passed open and infected seeds were taken out aseptically with the help of another flame sterilized forceps. The naturally $A$. rabiei infected seeds, thus obtained were planted on autoclaved chickpea seed meal agar (GSMA) medium in Petri plates and were incubated at 21 to $22^{\circ} \mathrm{C}$ for more than two weeks. The colonies of $A$. rabiei coming out of blighted seeds were isolated and purified by spore streak method (Pathak, 1986). The purified culture was identified and grown on GSMA slants and maintained at $5^{\circ} \mathrm{C}$ for further studies. The mass multiplication of $A$. rabiei inoculum was carried by the method of llyas and Khan (1986). When the entries were in early to mid pod stage, they were spray inoculated with spore suspension of $A$. rabiei $(18,000$ to 20,000 spores $/ \mathrm{ml})$. The inoculum of $A$. rabiei was prepared by the mass culturing technique described by llyas and Khan (1986). The inoculum spray was carried every day in the evening till the development of blight symptoms on susceptible variety. The development of disease was further aided by the continuous spray of tap water every day. The data of blight severity were recorded, when check line (Punjab-1) were completely infected and died to assess the level of resistance/susceptibility of each test line, using following 1-9 grades disease rating scale developed by Reddy and Nene (1979).

\section{Correlation and combining ability analysis for various quantitative traits}

The twenty resistant and moderately resistant lines were selected and grown in field during 2008 to 2009 via, 101, 620, 08-AG-004, $\mathrm{CH}-70 / 02$, CH-76/02, NOOR-91, Paidar-91, Pb-2000, 818, 870, K70005, K-70008, K-70022, CM-2008, YN-08004, AUG-27, M-98, 114, 115 and 117. The data was recorded for various traits including number of days taken to flowering, number of days taken to maturity, plant height, number of primary branches per plant, number of secondary branches per plant, number of pods per plant, number of seeds per plant, 100-seed weight, grain yield per plant and number of grain per plant. Analysis of variance for all characters was carried out using the method of Steel et al., (1997). Phenotypic $\left(r_{p}\right)$ and genotypic $\left(r_{g}\right)$ correlation coefficient was calculated as outlined by Kwon and Torrie (1964). Genetic advance (GA) was calculated by the following formula by Falconer (1989). Paidar-91, 620, Pb-2000, 101 and 870 were selected on the basis of resistance against $A$. rabiei and crossed in $5 \times 5$ diallel fashion in field during 2009 to 2010 . The combining ability analysis was performed using mean values following Model I of Griffing's method (1956). The statistical t-student test was applied to examine the effects of general combining ability (GCA) and specific combining ability (SCA). GCA/SCA ratios with a theoretical maximum of unity were computed according to Baker (1978) as follows: 
Table 1. Disease development during four months of 10 chickpea varieties/lines.

\begin{tabular}{|c|c|c|c|c|c|c|}
\hline \multirow{2}{*}{ Varieties } & \multicolumn{4}{|c|}{ Disease severity during } & \multirow{2}{*}{ Mean } & \multirow{2}{*}{ Response } \\
\hline & $1^{\text {st }}$ Month & $2^{\text {nd }}$ Month & $3^{\text {rd }}$ Month & $4^{\text {th }}$ Month & & \\
\hline 08-AG-004 & $0.67^{1 \mathrm{~m}^{*}}$ & $1.67^{\mathrm{kl}}$ & $2.67^{\mathrm{jk}}$ & $5.67^{d-f}$ & $2.67^{E}$ & MR \\
\hline K-70005 & $3.67^{h-j}$ & $4.67^{\mathrm{f}-\mathrm{h}}$ & $6.00^{\mathrm{de}}$ & $8.67^{\mathrm{a}}$ & $5.75^{\mathrm{B}}$ & MS \\
\hline K-70008 & $3.67^{h-j}$ & $4.67^{f-h}$ & $6.67^{\mathrm{cd}}$ & $8.67^{a}$ & $5.91^{\mathrm{B}}$ & MS \\
\hline K-70009 & $5.00^{e-g}$ & $7.33^{b c}$ & $8.67^{a}$ & $9.00^{a}$ & $7.50^{\mathrm{A}}$ & $S$ \\
\hline K-70022 & $1.67^{\mathrm{kl}}$ & $4.00^{g-i}$ & $5.00^{e-g}$ & $8.00^{\mathrm{ab}}$ & $4.67^{C}$ & MS \\
\hline $\mathrm{CH}-70 / 02$ & $0.33^{\mathrm{m}}$ & $1.67^{\mathrm{kl}}$ & $2.67^{j-k}$ & $5.67^{d-f}$ & $2.58^{\mathrm{E}}$ & MR \\
\hline $\mathrm{CH}-76 / 02$ & $0.33^{\mathrm{m}}$ & $1.67^{\mathrm{kl}}$ & $2.67^{j-k}$ & $5.67^{d-f}$ & $2.58^{\mathrm{E}}$ & MR \\
\hline CM-2008 & $1.00^{\mathrm{Im}}$ & $3.33^{\mathrm{ij}}$ & $4.33^{g i}$ & $7.33^{b c}$ & $4.00^{\mathrm{D}}$ & MS \\
\hline NOOR-91 & $0.33^{\mathrm{m}}$ & $1.67^{\mathrm{kl}}$ & $2.67^{\mathrm{jk}}$ & $5.67^{d-f}$ & $2.58^{\mathrm{E}}$ & MR \\
\hline YN-08004 & $1.00^{\mathrm{Im}}$ & $3.33^{\mathrm{ij}}$ & $4.33^{g-i}$ & $7.33^{b c}$ & $4.00^{\mathrm{D}}$ & MS \\
\hline Mean & $1.76^{\mathrm{D}}$ & $3.40^{C}$ & $4.57^{\mathrm{B}}$ & $7.17^{\mathrm{A}}$ & & \\
\hline AUG-27 & $1.00^{\mathrm{m}-\mathrm{o}^{*}}$ & $3.33^{h-j}$ & $4.33^{\mathrm{f}-\mathrm{h}}$ & $7.33^{b}$ & $4.00^{C}$ & MS \\
\hline M-98 & $1.00^{\mathrm{m}-\mathrm{o}}$ & $3.67^{g-i}$ & $4.67^{e-g}$ & $7.33^{b}$ & $4.17^{C}$ & MS \\
\hline Paidar-91 & $0.67^{\mathrm{m}-\mathrm{o}}$ & $1.67^{\mathrm{k}-\mathrm{m}}$ & $2.67^{i-k}$ & $5.67^{\mathrm{c}-\mathrm{e}}$ & $2.67^{\mathrm{D}}$ & MR \\
\hline $\mathrm{Pb}-2000$ & $0.33^{\text {no }}$ & $1.67^{\mathrm{k}-\mathrm{m}}$ & $3.00^{i-j}$ & $6.00^{\mathrm{cd}}$ & $2.75^{\mathrm{D}}$ & MR \\
\hline 101 & $0.00^{\circ}$ & $1.33^{1-n}$ & $2.33^{j-1}$ & $2.33^{j-1}$ & $1.50^{\mathrm{E}}$ & $\mathrm{R}$ \\
\hline 114 & $1.33^{1-n}$ & $3.67^{g-i}$ & $4.67^{e-g}$ & $7.33^{b}$ & $4.25^{C}$ & MS \\
\hline 115 & $1.33^{1-n}$ & $3.67^{g-i}$ & $4.33^{\mathrm{fth}}$ & $7.33^{b}$ & $4.17^{C}$ & MS \\
\hline 117 & $1.00^{\mathrm{m}-\mathrm{o}}$ & $3.33^{h-j}$ & $4.33^{\mathrm{f}-\mathrm{h}}$ & $7.33^{b}$ & $4.00^{C}$ & MS \\
\hline 205 & $3.67^{g-i}$ & $4.67^{e-g}$ & $6.67^{b c}$ & $8.67^{a}$ & $5.92^{B}$ & $S$ \\
\hline 620 & $0.00^{\circ}$ & $1.33^{1-n}$ & $2.33^{\mathrm{j}-1}$ & $2.33^{\mathrm{j}-1}$ & $1.50^{\mathrm{E}}$ & $\mathrm{R}$ \\
\hline 698 & $5.00^{d-f}$ & $7.33^{b}$ & $8.67^{a}$ & $9.00^{a}$ & $7.50^{A}$ & $\mathrm{HS}$ \\
\hline 781 & $1.33^{1-n}$ & $3.33^{h-j}$ & $4.33^{\text {th }}$ & $7.33^{b}$ & $4.08^{C}$ & MS \\
\hline 818 & $0.67^{\mathrm{m}-\mathrm{o}}$ & $1.67^{\mathrm{k}-\mathrm{m}}$ & $2.67^{i-k}$ & $5.67^{\mathrm{c}-\mathrm{e}}$ & $2.67^{\mathrm{D}}$ & MR \\
\hline 820 & $5.00^{d-f}$ & $7.33^{b}$ & $8.67^{a}$ & $9.00^{\mathrm{a}}$ & $7.50^{\mathrm{A}}$ & $\mathrm{HS}$ \\
\hline 870 & $0.33^{\text {no }}$ & $1.67^{k-m}$ & $2.67^{i-k}$ & $5.67^{c-e}$ & $2.58^{\mathrm{D}}$ & MR \\
\hline 1049 & $1.33^{1-n}$ & $3.33^{h-j}$ & $4.33^{\mathrm{fth}}$ & $7.33^{b}$ & $4.08^{C}$ & HS \\
\hline 1205 & $3.67^{g-i}$ & $5.00^{d-f}$ & $6.67^{b c}$ & $8.67^{a}$ & $6.00^{B}$ & $S$ \\
\hline 1288 & $3.67^{g-i}$ & $5.33^{d-f}$ & $6.67^{b c}$ & $8.67^{a}$ & $6.08^{B}$ & $S$ \\
\hline 4025 & $1.67^{\mathrm{k}-\mathrm{m}}$ & $3.33^{h-j}$ & $4.33^{\mathrm{fth}}$ & $7.33^{b}$ & $4.17^{C}$ & MS \\
\hline 5006 & $1.33^{1-n}$ & $3.33^{h-j}$ & $4.33^{\mathrm{fth}}$ & $7.33^{b}$ & $4.08^{C}$ & MS \\
\hline Mean & $1.72^{\mathrm{D}}$ & $3.50^{C}$ & $4.63^{B}$ & $6.88^{A}$ & & \\
\hline
\end{tabular}

*Means sharing similar letters do not differ significantly at $p \leq 0.05$ by Duncan's multiple range test, LSD $=0.504$, C.V. $=14.66 \%\left(1^{\text {st }}\right.$ 10 genotypes), LSD $=0.46$, C.V. $=13.54 \%$ (last 20 genotypes).

$\mathrm{GCA} / \mathrm{SCA}=2 S_{\mathrm{gi}} /\left(2 S_{\mathrm{gi}}+2 S_{\mathrm{sii}}\right)$

Where gi is the GCA effect of parent $i$ and sij is the SCA effect of the Cross $i \times j$.

\section{RESULTS AND DISCUSSION}

Field screening of chickpea germplasm for the source of resistance against $A$. rabiei revealed that none of the test lines/cultivars possessed immunity against this pathogen. However, from Table 1 two lines viz. 101 and 620 exhibited resistance. Eight lines viz. 08-AG-004, CH70/02, CH-76/02 NOOR-91; viz. Paidar-91, Pb-2000, 818 and 870 exhibited moderately resistant reaction against the disease. Thirteen lines that is, K-70005, K-70008, K70022, CM-2008, YN-08004, AUG-27, M-98, 114, 115, 117, 781, 1049, 4025 and 5006 revealed moderately susceptible reaction to the disease. Four lines that is, K$70009,205,1205$ and 1288 were found susceptible to the disease. Two lines viz. 698 and 820 were highly susceptible. This revealed that there are good source of resistance in existing chickpea germplasm lines/mutant/cultivars that can further be exploited and incorporated into commercial cultivars. Many other workers have also reported the occurrence of moderate resistance to Ascochyta blight. Many sources of 
Table 2. Estimates of genetic components.

\begin{tabular}{lcccccccc}
\hline Quantitative traits & G V & PV & EV & $\begin{array}{c}\text { GCV } \\
(\%)\end{array}$ & $\begin{array}{c}\text { PCV } \\
(\%)\end{array}$ & $\begin{array}{c}\text { ECV } \\
(\%)\end{array}$ & $\begin{array}{c}\text { Broad-sense } \\
\text { heritability } \\
\left.\mathbf{h}^{2}\right) \%\end{array}$ & $\begin{array}{c}\text { Genetic } \\
\text { advance } \\
(\%)\end{array}$ \\
\hline Days taken to flowering & 17.636 & 21.257 & 2.5410 & 20.713 & 22.74 & 0.4359 & 83.0 & 30.955 \\
Days taken to maturity & 0.208 & 0.209 & 1.1564 & 135.41 & 135.547 & 0.71 & 99.80 & 36.606 \\
Plant height & 28.251 & 33.201 & 2.8369 & 18.623 & 20.188 & 3.53 & 85.10 & 49.586 \\
Primary branches per plant & 0.565 & 0.62 & 0.0058 & 2.0204 & 2.309 & 3.01 & 91.10 & 99.126 \\
Secondary branches per plant & 0.007 & 0.013 & 0.1553 & 22.089 & 28.555 & 4.84 & 59.80 & 1.364 \\
Biomass per plant & 1.248 & 1.751 & 8.2708 & 34.29 & 40.612 & 3.40 & 71.30 & 21.910 \\
Pods per plant & 394.792 & 430.403 & 17.0445 & 40.642 & 42.435 & 8.45 & 91.70 & 635.35 \\
Seeds per pod & 0.015 & 0.023 & 9.2141 & 24.239 & 29.776 & 0.8305 & 66.30 & 2.676 \\
100-seed weight & 0.075 & 0.172 & 12.8043 & 20.205 & 30.544 & 4.13 & 43.80 & 13.221 \\
Grain yield per plant & 0.022 & 0.028 & 1.1554 & 20.418 & 23.256 & 3.53 & 77.10 & 3.789 \\
Grains per plant & 21.7217 & 34.5260 & 5.8043 & 5.38 & 6.78 & 0.6589 & 62.9 & 5.1755 \\
\hline
\end{tabular}

resistance to $A$. rabiei have been reported during the last 50 years and generally these reports were based either on field observation during natural epidemics or on artificial inoculation tests in the field or greenhouse (Bashir et al., 1985, 2006; Alam et al., 2003; lqbal et al., 2004; Chaudhary et al., 2005). While Haq et al. (1981) identified blight resistant chickpea mutants CM-72 and CM-68 from his irradiated material. Most of the previously reported resistant cultivars have lost their resistance, probably due to the appearance of new physiological races of $A$. rabiei and need replacement. Similarly, Jalali et al. (1983) tested various genotypes for resistance against $A$. rabiei and concluded that out of 150 lines sown in field and green house for there reaction against A. rabiei, seven showed moderate resistance.

Genetic parameters of yield and their components are given in Table 2. In the present study, the highest genotypic variances were found for NPP (394.792), NDF (17.636) and $\mathrm{PH}$ (28.251) while lowest genotypic variance was found for SBP (0.007), SPP (0.015) and GPP (0.022). The highest phenotypic variances were found for NPP (430.403), NDF (21.257) and GPP (34.526) while lowest for GYP (0.028), SPP (0.023) and NSB (0.013). The highest environmental variance was found for NPP (17.0445) while lowest for NPB (0.0058). The highest genotypic coefficient of variances was found for NDM (135.41\%), NPP (40.642\%) and BM (34.29\%) while lowest genotypic coefficient of variance was found for NPB (2.0204\%) and GPP (5.038). The highest phenotypic coefficient of variances was found for NDM (135.545\%), NPP (42.435\%) and BM (40.612\%) while lowest phenotypic coefficient of variance was found for NPB $(2.309 \%)$. The highest environmental coefficient of variances was found for NPP (8.45\%) while lowest environmental coefficient of variance was found for NDF $(0.4359 \%)$. Similar findings were reported by Adhikari and Pandey (1982). The higher values of genetic advance were found for NPP (635.35), NPB (99.126\%), and $\mathrm{PH}(49.586 \%)$. The greater values of genetic advance indicated that NPP, PH and NPB can be used for selecting higher yielding genotypes (Raval and Dobariya, 2003). The highest heritability (99.80) was found for number of taken to maturity and range of heritability from 62.9 to 99.80 . The greater values of heritabilities were found for PH, SPP, GPP, NPB, GYP and NPP while lowest values were for 100-seed weight. The higher value of heritability for grain yield per plant, number of grains per plant and pods per plant indicates that these characters can be used as the genetic parameters for the improvement and selection of high yielding genotypes. These results were in accordance with the findings of Dasgupta et al. (1992). The NDF, NDM, PH, SPP, GPP, NPB, GYP, NPP, BMP and GY per plant indicated high heritability coupled with genotypic variation. Crop improvement could be possible by simple selection because high heritability coupled with high genotypic variation revealed the presence of an additive gene effect (Noor et al., 2003). On the other hand, low heritability coupled with low genotypic variation was observed for 100-seed weight, NPB and NSP. The results indicated that these traits were greatly influenced by the environment (Arshad et al., 2002).

A positive and significant genotypic and phenotypic correlation coefficient (Table 3 ) for number of days to flowering (NDF) with NDM, NPB, PH, NGP, NSP but negative but significant phenotypic correlation was found between NDF and NSP. The positive and significant genotypic and phenotypic correlation coefficient for number of days to maturity (NDM) with GYP and NPP but negative and significant genotypic correlation was found for PH, NPB, 100-seed weight and NSP. A higher genotypic and phenotypic correlation was found between plant height and NPB while negative and significant genotypic correlation was found for NSB, NSP, NPP, 100-seed weight but positive and significant for NSB, BM and NSP at phenotypic level. The number of pods per 
Table 3. Genotypic and phenotypic correlation of various quantitative traits.

\begin{tabular}{|c|c|c|c|c|c|c|c|c|c|c|c|}
\hline Traits & $\mathbf{r}$ & NDM & PH & NPP & NPB & NSB & DW & 100-SW & NSP & NGP & GY \\
\hline \multirow{2}{*}{ NDF } & $\mathrm{G}$ & $0.354813^{* *}$ & $0.256431^{*}$ & 0.181193 & $0.514416^{*}$ & -0.27061 & $-0.33977^{*}$ & 0.173216 & $-0.53664^{\star *}$ & $0.541083^{*}$ & $0.731261^{*}$ \\
\hline & $P$ & $0.253689^{*}$ & $0.235610^{*}$ & $0.54101^{*}$ & $-0.322984^{*}$ & $-0.29656^{*}$ & -0.149231 & 0.121843 & $-0.35197^{*}$ & 0.083109 & $0.31109^{*}$ \\
\hline \multirow{2}{*}{ NDM } & $\mathrm{G}$ & & $-0.260310^{*}$ & $0.245055^{\star}$ & $-0.25962^{*}$ & $0.229331^{*}$ & -0.102894 & $-0.45236^{*}$ & $-0.26711^{*}$ & -0.210021 & $0.91812^{* \star}$ \\
\hline & $P$ & & 0.120765 & $0.556464^{\star *}$ & -0.225827 & 0.101509 & -0.21344 & -0.19709 & -0.102254 & -0.2153 & $0.452501^{*}$ \\
\hline \multirow{2}{*}{$\mathrm{PH}$} & $G$ & & & $-0.341889^{*}$ & $0.62383^{* *}$ & $-0.60747^{\star *}$ & -0.12358 & $-0.31721^{*}$ & $-0.46792^{*}$ & -0.12127 & -0.004263 \\
\hline & $\mathrm{P}$ & & & $0.643174^{* *}$ & $0.430369^{\star *}$ & $-0.38764^{*}$ & $-0.16821^{*}$ & -0.13808 & $-0.27691^{*}$ & -0.10112 & -0.050191 \\
\hline \multirow{2}{*}{ NPP } & $\mathrm{G}$ & & & & -0.23156 & $0.55029^{\star *}$ & $0.293602^{*}$ & -0.21152 & $-0.30691^{*}$ & -0.18041 & 0.089245 \\
\hline & $\mathrm{P}$ & & & & $-0.330664^{\star *}$ & $0.351766^{\star \star}$ & 0.191958 & -0.102302 & -0.15795 & -0.120649 & 0.096244 \\
\hline \multirow{2}{*}{ NPB } & $G$ & & & & & 0.141073 & -0.12771 & -0.22406 & $0.475881^{*}$ & $0.31826^{\star *}$ & $-0.78974^{* *}$ \\
\hline & $\mathrm{P}$ & & & & & 0.07334 & 0.025468 & -0.13853 & $0.217878^{*}$ & $0.289544^{*}$ & $-0.59516^{*}$ \\
\hline \multirow{2}{*}{ NSB } & $G$ & & & & & & 0.220983 & $-0.47098^{\star \star}$ & $0.365295^{\star}$ & $-0.59664^{*}$ & $0.497671^{*}$ \\
\hline & $\mathrm{P}$ & & & & & & 0.021354 & $-0.351205^{*}$ & $0.285029^{*}$ & $-0.269083^{\star}$ & $0.26691^{*}$ \\
\hline \multirow{2}{*}{ DW } & $\mathrm{G}$ & & & & & & & $-0.456208^{*}$ & $0.776128^{*}$ & $0.356453^{* *}$ & $0.3406^{* *}$ \\
\hline & $\mathrm{P}$ & & & & & & & -0.1603 & 0.29634 & $0.496297^{\star *}$ & 0.182493 \\
\hline \multirow{2}{*}{$100-S W$} & $\mathrm{G}$ & & & & & & & & $0.468291^{* *}$ & -0.156499 & $-0.46452^{* *}$ \\
\hline & $P$ & & & & & & & & $0.125769^{*}$ & $-0.64323^{*}$ & $-0.22203^{* *}$ \\
\hline \multirow{2}{*}{ NSPP } & $G$ & & & & & & & & & $0.42528^{*}$ & $-0.34051^{*}$ \\
\hline & $\mathrm{P}$ & & & & & & & & & 0.152133 & $-0.26408^{*}$ \\
\hline \multirow{2}{*}{ NGP } & $\mathrm{G}$ & & & & & & & & & & -0.13327 \\
\hline & $\mathrm{P}$ & & & & & & & & & & $-0.2177^{*}$ \\
\hline
\end{tabular}

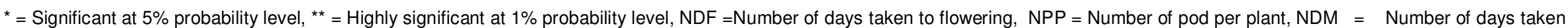

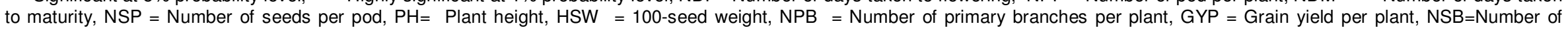
secondary branches per plant, NGP $=$ Number of grains per plant.

plant (NPP) was strongly and positively correlated with NSB and BM at genotypic and phenotypic levels while negative for NSP. Selection can be made on the basis of NSP (Raval and Dobariya, 2003). The strong genotypic and phenotypic correlation was found for NPB, BM and NSB with
NSP and GYP. 100-seed weight was also strongly and positively correlated with NSP and GYP.

The highest specific combining ability effects 
Table 4. Combining ability analysis for various quantitative traits.

\begin{tabular}{|c|c|c|c|c|c|c|c|c|c|c|c|}
\hline Genotypes (SCA) & NDF & NDM & PH & NPP & NPB & NSB & DM & $100-S W$ & NSP & NGP & GYP \\
\hline Paidar-91 & 0.50 & -0.229 & 0.35 & 1.425 & 0.004 & 0.100 & 0.960 & 0.417 & 0.019 & 1.677 & -0.537 \\
\hline $\mathrm{Pb}-2000$ & 0.40 & -0.146 & -1.917 & -0.613 & 0.006 & -0.038 & 0.398 & 0.206 & -0.016 & -0.810 & 0.473 \\
\hline 620 & -1.0 & 0.688 & 1.142 & 3.921 & -0.039 & 0.096 & 1.277 & -0.653 & -0.015 & 1.565 & 0.144 \\
\hline 101 & 0.586 & 0.312 & 0.425 & -4.733 & 0.030 & -0.158 & -2.635 & 0.029 & 0.012 & -2.431 & -0.079 \\
\hline 870 & -0.250 & 0.5 & 1.167 & 2.833 & 0.067 & 0.167 & 0.833 & 0.893 & 0.213 & 2.033 & 0.333 \\
\hline \multicolumn{12}{|l|}{ Direct crosses (GCA) } \\
\hline Paidar-91 vs Pb-2000 & 1.569 & 1.146 & 0.833 & 3.904 & 0.070 & 0.267 & 1.752 & -0.645 & 0.062 & 4.110 & 0.181 \\
\hline Paidar-91 vs 620 & -2.333 & 0.062 & 5.533 & -0.467 & -0.036 & 0.704 & 3.819 & -0.296 & -0.019 & -7.435 & 0.229 \\
\hline Paidar-91 vs 101 & 0.333 & -0.604 & 0.2 & 2.617 & 0.004 & 0.171 & 0.085 & 0.147 & -0.031 & 0.990 & 1.895 \\
\hline Paidar-91 vs 870 & 1.978 & 0.146 & 2.833 & 6.592 & -0.029 & -0.321 & 1.023 & 0.376 & 0.007 & -3.869 & -1.747 \\
\hline Pb-2000 vs 620 & -1.750 & 1.396 & 2.433 & 4.229 & -0.016 & 0.100 & 1.335 & 0.068 & 0.097 & -0.631 & 0.021 \\
\hline $\mathrm{Pb}-2000$ vs 101 & -0.475 & -0.854 & 3.7 & 0.492 & -0.042 & -0.021 & -0.931 & 0.191 & 0.012 & 2.473 & 1.229 \\
\hline Pb-2000 vs 870 & 1.000 & 0.167 & 2.566 & 4.033 & 0.167 & 0.643 & 1.067 & 0.583 & 0.321 & 3.833 & 1.067 \\
\hline 620 vs 101 & 2.553 & 0.963 & 0.666 & 7.233 & 0.033 & 0.167 & 2.033 & 0.331 & 0.022 & 4.064 & 0.869 \\
\hline 620 vs 870 & 3.366 & -0.883 & 2.333 & 3.033 & 0.021 & 0.500 & 3.451 & 0.312 & -0.234 & -3.213 & 0.584 \\
\hline 101 vs 870 & 2.443 & 1.223 & 4.833 & 2.333 & 0.183 & 0.433 & 1.833 & 0.643 & 0.689 & -2.083 & 0.674 \\
\hline \multicolumn{12}{|c|}{ Reciprocal crosses (GCA) } \\
\hline Pb-2000 vs Paidar-91 & 1.333 & 1 & -4.583 & -2.450 & -0.002 & -0.400 & -1.983 & -0.308 & -0.073 & 2.233 & -0.308 \\
\hline 620 vs Paidar-91 & 3.333 & 0.167 & 0.25 & -4.033 & -0.120 & -0.500 & -1.183 & 0.323 & -0.023 & -0.733 & -1.640 \\
\hline 101 vs Paidar-91 & 2.333 & -0.167 & 0.658 & 7.200 & -0.095 & 0.067 & 1.533 & -0.025 & 0.032 & -1.617 & 0.562 \\
\hline 870 vs Paidar-91 & 3.254 & 1.167 & 2.567 & 3.783 & 0.052 & -0.317 & -4.533 & 0.782 & -0.048 & -4.717 & 0.448 \\
\hline 620 vs Pb-2000 & 2.000 & 0.833 & -2.867 & -8.600 & -0.047 & 0.067 & 2.833 & -0.967 & 0.032 & 0.017 & 3.033 \\
\hline 101 vs $\mathrm{Pb}-2000$ & -1.921 & -0.333 & 2.258 & 9.517 & 0.068 & 0.167 & -0.317 & -1.617 & -0.018 & -2.017 & 0.037 \\
\hline 870 vs Pb-2000 & 2.053 & 1.333 & 2.333 & 5.621 & 0.333 & 0.132 & 1.067 & 0.856 & 0.333 & 3.833 & 0.583 \\
\hline 101 vs 620 & 3.230 & 2.167 & 1.00 & 4.364 & 0.321 & -0.053 & 1.233 & 0.963 & 0.435 & 1.167 & 0.200 \\
\hline 870 vs 620 & 3.353 & 2.000 & 0.833 & 2.654 & 0.583 & 0.203 & -2.083 & 0.016 & 0.564 & 2.333 & 0.167 \\
\hline 870 vs 101 & 2.235 & -0.443 & 0.333 & 4.333 & 0.643 & 0.643 & -1.033 & 2.035 & 0.648 & 5.033 & 0.583 \\
\hline
\end{tabular}

(Table 4) of genotypes Paidar-91, 620 and 870 for $\mathrm{PH}$ were found as $0.35,1.142$ and 1.167 respectively, for NPP were $1.425,3.921$ and 2.883 respectively. The genotype 620 has 1.277 for dry matter and 870 has 2.033 for NGP while the SCA effects for other traits were low and negative. The direct crosses Paidar- 91 vs $\mathrm{Pb}$ 2000, Paidar-91 vs $870, P b-2000$ vs 870,620 vs 101,620 vs 870 and 101 vs 870 have higher general combining ability effects for number of days taken to flowering. All reciprocal crosses have higher general combining ability effects while
101 vs $\mathrm{Pb}-2000$ has higher but negative general combining ability effects. The direct crosses Paidar-91 vs Pb-2000, Pb-2000 vs 620 and 101 vs 870 and reciprocal crosses $\mathrm{Pb}-2000$ vs Paidar91, 870 vs Paidar-91, 870 vs Pb2000, 101 vs 620 and 870 vs 620 have higher general combining 
ability effects for number of days taken to maturity. All other direct and reciprocal crosses have lower general combining ability effects. All direct crosses except Paidar91 vs 101,620 vs 101 and Paidar-91 vs Pb-2000 which were heaving lower value of GCA and reciprocal crosses $\mathrm{Pb}-2000$ vs Paidar-91, 620 vs $\mathrm{Pb}-2000$, have higher negative GCA value for plant height. The similar results were obtained by Bakhsh et al. (2003), Yadavendra and Kumar (2006) and Hegde et al. (2007). The GCA effect for NPP were higher for all direct crosses except Paidar91 vs 620 (negative GCA) and Pb-2000 vs 101 (positive GCA), all of the reciprocal crosses have higher GCA effect but $\mathrm{Pb}-2000$ vs Paidar-91, 620 vs Paidar-91 and 620 vs Pb-2000 have higher but genitive GCA effects. The GCA effect for NPB were lower for all direct crosses except $\mathrm{Pb}-2000$ vs 870 and 101 vs 870 higher GCA effects. The similar results were obtained by Bakhsh et al. (2003), Yadavendra and Kumar (2006) and Hegde et al. (2007). The reciprocal cross 870 vs 101 has highest GCA effect for NBP and Pb-2000 vs Paidar-91 has lowest GCA effect. The direct cross Paidar-91 vs 620 has highest GCA effect for NSB while Pb-2000 vs 101 has lowest and negative GCA effect. The reciprocal cross 870 vs 101 has highest GCA effect for NSB while $\mathrm{Pb}-2000$ vs Paidar-91 has lowest and negative GCA effect.

The direct cross 620 vs 870 has highest GCA effect for DM while Pb-2000 vs 101 has lowest and negative GCA effect. The reciprocal cross 620 vs Pb-2000has highest GCA effect for DM while 870 vs Pb-2000 has highest but negative GCA effect. The direct cross 101 vs 870 has highest GCA effect for 100 -seed weight while $\mathrm{Pb}-2000$ vs 620 has lowest and negative GCA effect. The reciprocal cross 870 vs 101 highest GCA effect for 100-seed weight while 101 vs Pb-2000 has highest but negative GCA effect. The same results were obtained by Bakhsh et al. (2003) and Deshmukh and Bhapkar (2006). The direct cross 101 vs 870 has highest GCA effect for NSP while $\mathrm{Pb}-2000$ vs 101 has lowest and negative GCA effect. The reciprocal cross 870 vs 101 highest GCA effect for NSP while 101 vs Pb-2000 has lowest but negative GCA effect. The direct cross Paidar-91 vs Pb-2000, Pb-2000 vs $101, \mathrm{~Pb}-2000$ vs 620 , and 620 vs 101 have highest GCA effect for NGP while Paidar-91 vs 620 has highest and negative GCA effect. The reciprocal cross 870 vs 101,870 vs 620,870 vs Pb-2000, 101 vs 620 and $P b-$ 2000 vs Paidar- 91 have higher GCA effect for NGP while 870 vs Paidar-91 has higher but negative GCA effect. The similar results were obtained by Bakhsh et al. (2003), Yadavendra and Kumar (2006) and Hegde et al. (2007). Paidar-91 vs 101, Pb-2000 vs 101 and Pb-2000 vs 870 have higher GCA effects for GYP while others have lower effects from reciprocal crosses 620 vs Pb-2000 has higher GCA effects. It indicates that these crosses can be used for higher yielding chickpea genotypes which also have resistance against $A$. rabiei. The similar results were obtained by Bakhsh et al. (2003), Deshmukh and Bhapkar (2006), Yadavendra and Kumar (2006) and
Hegde et al. (2007).

\section{Conclusions}

It is concluded from three experiments that the genotypes that exhibited resistance against the $A$. rabiei showed that these genotypes have strong genotypic and phenotypic correlation for NPB, BM and NSB with NSP and GYP. 100-seed weight was strongly and positively correlated with NSP and GYP. The crosses Pb-2000 vs 870,620 vs 101 , Paidar-91 vs 870,101 vs 870,620 vs 101,101 vs 620,870 vs 620,101 vs Paidar-91 and 870 vs $\mathrm{Pb}-2000$ showed good GCA effects for various quantitative traits. So these five lines Paidar-91, 620, Pb2000, 101 and 870 can be used as good yielding chickpea genotypes heaving resistance against $A$. rabiei.

\section{REFERENCES}

Acikgoz N, Karaca M, Er C, Meyveci K (1994). Chickpea and lentil production in Turkey. In: Muehlbauer F.J. and W.J. Kaiser (Eds.) Expanding the Production and Use of Cool Season Food Legumes. Kluwer Academic Publ., The Netherlands. pp. 388-398.

Ahmad HU, Chang KF, Hwang SF, Gossen BD, Howard RJ, Warkentin TD (2006). Component of disease resistance in desi and kabuli chickpea varieties against Ascochyta blight. J. Plant Path. 5(3):336342.

Adhikari G, Pandey MP (1982). Genetic variability in some quantitative characters on scope for improvement in chickpea (Cicer arietinum L.). Chickpea Newsletter, June ICN. 7:4-5.

Alam SS, Hassan M, Haq MA, Shah TM, Atta BM, Syed H (2003). Screening for Ascochyta blight resistance in chickpea. Mycopathology 1(2):129-130.

Anonymous (2009-2010). Economic survey of Pakistan, Government of Pakistan, Ministry of Food, Agriculture and Livestock, Economics Wing, Islamabad.

Anonymous (2006-2007). Agricultural Statistics of Pakistan, Ministry of Food, Agriculture and Cooperatives, Islamabad.

Armstrang CL, Chongo G, Gossen BD, Duczek CJ (2001). Mating type distribution and incidence of the teleomorph of Ascochyta rabiei (Didymella rabiei) in Canada. Can. J. Plant Pathol. 23:110-113.

Arshad M, Bakhsh A, Bashir M, Haqqani AM (2002). Determining the heritability and relationship between yield and yield components in chickpea (Cicer arietinum L.). Pak. J. Bot. 34:237-245.

Aslam M (1984). A review of research on chickpea blight fungus in Pakistan. In: Chickpea, (Eds.): M.C. Sexena and K.B Singh, ICARDA, Aleppo, Syria. P. 255.

Bakhsh A, Wahid MA, Bugti RA, Zahid MA, Ali S (2003). Evaluation of Chickpea Germplasm for Semi Arid Zones of Balochistan. Int. J. Agric. Biol. 2:113-116.

Bashir A, Yaqoob M, Rahim M, Khalid R, Najibullah (2006). Source of resistance against disease complex in chickpea. Ind. J. Biol. Sci. $3(1): 660-663$.

Bashir M, Alam SS, Qureshi SH (1985). Chickpea germplasm evaluation for resistance to Ascochyta blight under artificial conditions. Int. Chickpea Newsletter No. 12:24-26.

Bashir N, Hashmi MI, Jamil FF (1997). Induction of systemic acquired resistance by oxalic acid in chickpea (Cicer arientinum L.) against Ascochyta rabiei. Pak. J. Phytopathol. 9(1):18-20.

Chaube HS, Pandey BK (1986). Transmission of seed borne inoculum of Ascochyta rabiei (Pass.) Labr. In chickpea seedling. Bull. Pure Appl. Sci. 5:18.

Chaudhary MA, Faquir M, Muhmmad A (2005). Screening of chickpea germplasm for resisance to Ascochyta blight. J. Agric. Res. 43(3):229-233. 
Dasgupta T, Islam MO, Gayen (1992). Genetic variability and analysis of yield components in chickpea (Cicer arietinum L.). Annals Agric. Res. 13:157-160 [Plant Br. Abst. 64(7):7129; 1994].

Deshmukh RB, Bhapkar DG (2006). Heterosis and combining ability for yield and its components in chickpea. Ind. J. Agric. Sci. 6:225233.

Falconer DS (1989). Introduction to quantitative genetics. $3^{\text {rd }}$ Ed. Logman Scientific \& Technical, Logman House, Burnt Mill, Harlow, Essex, England.

Griffing B (1956). Concept of general and specific combining ability in relation to diallel crossing systems. Aust. J. Biol. Sci. 9:463-493.

Haq MA, Shakoor A, Sadiq M, Hussain M (1981). Induction of Ascochyta blight resistant mutants in chickpea. Mutation Breeding Newsletter No. 17: 5-6 FAO/IAEA.

Hegde VS, Yadav SS, Kumar J (2007). Heterosis and combining ability for biomass and harvest index in chickpea under a drought-prone, short-duration environment. Euphytica 157:223-230.

Huisman J, Van der Poel AFB (1994). Aspects of the nutritional quality and use of cool season food legumes in animal feed. P. 53-76.

llyas MB, A lqbal (1986). Evaluation of fungicides for the eradication of seed borne Ascochyta rabiei fungus. Pak. J. Agric. Sci. 23(3-4):145149.

Ilyas MB, Khan IU (1986). A low cost easy technique for the culturing of Ascochyta rabiei fungus. Pak. J. Agric. Sci. 23(1):60.

lqbal SM, Bakhsh A, Zahid MA, Haqqani AM (2004). Screening of resistance against Ascochyta blight in chickpea. Mycopathology 2(1):7-10.

lqbal SM, Bukhsh A, Shabbir A, Bashir M (1989). Field evaluation of fungicides for Ascochyta blight in lentil. Sar. J. Agri. 5(3): 307-308.

lqbal SM, Ghafoor A, Bakhsh A, Bashir M (2002). Disease resistance status of chickpea genotypes against Ascochyta blight. Pak. J. Phytopathol. 14(2):135-139.

Jamil FF, Sarwar M, Haq I, Bashir N (1995). Identification of pathotypes in Ascochyta rabiei (Pass.) Labr. The cause of chickpea blight in Pakistan. Pak. J. Bot. 27:193-199.

Jimenez-Diaz RM, Crino P, Halila MH, Mosconi C, Trapero-Casas AT (1993). Screening for resistance to Fusarium wilt and Ascochyta blight in chickpea. In: K.B. Singh and M.C. Saxena (ed.) Breeding for Stress Tolerance in Cool-Season Food Legumes. ICARDA. John Wiley \& Sons, Chichester, UK. pp. 77-95.

Kaiser WJ (1992). Epidemiology of Ascochyta rabiei. In: Disease Resistance Breeding in Chickpea. K.B. Singh \& M.C Saxena. Aleppo Syria: ICRDA. pp. 117-143.

Kwon SH, JH Torrie (1964). Heritability and interrelationship of two soybean (Glycine max L.) populations. Crop Sci. 4:196-198.

Malik MA, Bashir M (1984). Strategies for controlling gram blight. Prog. Farm. 4(5):21-23.

Muehlbauer FJ, KB Singh (1987). Genetics of chickpea (Cicer arietinum L.). P. 99- 126. In: M.C. Sexana and K.B. Singh (eds:), The chickpea CAB International, Wallingford, Oxon, OX10 8DE UK.
Mucella T, Muzaffer I, Muehlbauer FJ (2004). QTL Analysis of Ascochyta Blight Resistance in Chickpea. Turk. J. Agric. 28: 183-187.

Nene YL, Reddy MV (1987). Chickpea diseases and their control. In: Saxena MC, Singh KB (eds) The Chickpea. CAB International, Oxon., pp. 233-270.

Nene YL (1982). A review of ascochyta blight of chickpea. Tropical Pest Manage. 28:61-70.

Noor F, Ashaf M, Ghafoor A (2003). Path analysis and relationship among quantitative traits in chickpea (Cicer arietinum L.). Pak. J. Biol. Sci. 6:551-555

Pathak MV (1986). Laboratory manual of plant pathology $2^{\text {nd }}$ Edit. Oxford IBH Pub. Co. New Delhi, pp. 23-25.

Rauf CA, Malik MR, lqbal SM, Rahat S, Hussain S (1996). Fungicides an economic tool to enhance productivity and net returns in chickpea crop. Sar. J. Agric. 12(4):445-448.

Raval LJ, Dobariya KL (2003). Yield components in improvement of chickpea (Cicer arietinum L.). Ann. Agric. Res. 24:789-794.

Reddy MV, Singh (1984). Laboratory techniques for isolation and multiplication of Ascochyta rabiei. In: Proc. Symp. On the Role of Induced Mutations in Crop Improvement. Osmania Univ. Hyderabad, India. pp. 103-104.

Reddy MV, Nene YL (1979). A case of induced mutation in chickpea for Ascochyta blight resistance. In: Proc. symp. On thr role induced mutation in crop improvement. Osmania Univ. Hyderabad, India. pp. 398-408.

Steel RGD, Torrie JH, Deekey DA (1997). Principles and procedures of statistics. A Biometrical Approach. $3^{\text {rd }} \mathrm{Ed}$. McGraw Hill Book Co. Inc. N.Y. USA.

Yadavendra JP, Kumar S (2006). Combining ability in chickpea. Ind. J. Gene. Plant Br. 3:171-185. 